\title{
Protecting Earth? Rappaport's Vision of Rituals as Environmental Practices
}

\author{
Anne-Christine Hornborg \\ Linköping University, Sweden \\ E-mail: Anne-Christine.Hornborg@liu.se
}

KEYWORDS Technology as Practice. Ritual and Modernity. Characteristics of Ritual. Ritual. Protecting Places

\begin{abstract}
In this article I discuss the characteristics of ritual practices, according to Roy Rappaport's general theory of ritual. I start by discussing technology as a kind of ritual product of science and then briefly present Rappaport's ritual theory as an aid in understanding how the Mi'kmaq Indians of Cape Breton Island, Nova Scotia, employed rituals in their efforts to protect a sacred mountain from being turned into a superquarry. In Ritual and Religion in the Making of Humanity, Rappaport discusses the concept of the ecosystem as a product of modern Western society, emanating from scientific epistemology rather than religious dogma. Rappaport also identifies "ecological thinking" in what he calls The Book. Although not expressed in terms of modern ecology, he suggests, such pre-modern thought is an adequate medium for protecting environmental values. His vision is to bring these two separate cosmologies closer, in order to emphasize the moral responsibility of humans everywhere on this planet. It is impossible, Rappaport would say, to do something without simultaneously affecting social relations and the environment. Humanity has the power and the technology to destroy places and ecosystems, if morality is left without consideration. Rappaport's vision was to combine the moral efficacy of ritual with the analytical validity of ecological thinking. But how can modern, de-traditionalized humans create such a synthesis, that reckons with both practical effects and moral implications of human agency?
\end{abstract}

When my husband and I had the privilege to spend some days in the middle of the 1990s with Roy Rappaport during his visit to Lund University, including showing him the southern part of Sweden, I knew that I had not only met a brilliant scholar but also a visionary, who would leave important footprints to find new ways of approaching religion and rituals. Rappaport was in the middle of putting together his grand opus Ritual and Religion in the Making of Humanity (1999), which would compile decades of work, including his fieldwork in New Guinea and systematic studies of the relationship between humans and the environment. In his earlier studies he had already pointed out that religion and rituals had advantages for humankind when it comes to building sustainable and reliable systems for society and, in the long run, the environment (see Rappaport, 1968).

It was Rappaport's friend Keith Hart who did the final editing of Rappaport's last book, since "Skip" died of cancer in 1997. Rappaport was greatly concerned about the state of modern society, and Hart writes (1999: xv) in his foreword to Ritual and Religion that Rappaport had a vision of how to "inform future attempts to construct a religion compatible with the scientific laws ruling a world for which humanity is ultimately responsible, as that part of life on this planet which is able to think."
It was long thought among sociologists (starting with Weber and Durkheim) that science would be the final end of the long evolution of human cognition, and modernity was the system that would make religion a thing of the past. But contemporary development in the world has not proved this thesis. Islam has strengthened its position in modern states, and although Sweden is said to be one of the most secular states in the world, a number of new ritualized practices have emerged that add spirituality to formerly secular practices (e.g. therapy). These modern, spiritualized practices seem to attract stressed and burnt-out modern souls and offer as healing recipe ways to find the "inner capacity" of a person or means to "develop the Higher Self" (see Heelas, 2002: 360).

Science has also been criticized in late modern society for not being as value-free as depicted by the earlier scholars, and thus biased with concealed ideology. Marx criticized science for being a powerful discourse, and its offspring technology for being in the service of the powerful elite. Environmental historians, such as Carolyn Merchant (1980), and ecofeminists have claimed that modern science is a product of the sixteenth and seventeenth century and characterized by male dominance over nature and women. Thus technology works as an 
ideological tool for modern science, and as "the ritual of science," it has been a weapon to dominate nature, women and the colonies. Also, we have witnessed in the shadow of modernity a most horrifying example of this. When race biology, masked as science, was put in motion with the aid of modern technology, one of the most terrible event and places ever created was constructed: the holocaust and the concentration camps (Bauman, 1989).

\section{TECHNOLOGY AS PRACTICE}

Modern technology has been the most radical transforming practice of people's relation to each other and to places. Highways cross the landscape, industrial constructions cut off people from places and change the environment, and cities have created new technologically designed spaces for city dwellers to relate to. Technology can create fear of places, such as a nuclear power plant and the fear of radioactivity, or the fear of roads and cars that might hurt playing children. In war, high technology is used for destroying places, like the missiles fired in July 2006 from both Israel and the Hezbollah. Although invented by humans, technology can be the most inhuman activity. It makes suffering faces invisible, since the perpetrators do not have to meet their victims on today's battlefield. Long-distance missiles do not have the human capacity to experience the fear of Lebanese or Israelites losing their lives or homes when they are hit.

Social relations in modern society are also results of technology, since technology is unequally distributed between countries and classes (Alf Hornborg, 2001). Technology can also create fictitious worlds of relations and places, such as the pseudo-relationship to characters in television series or the battlefields in children's play stations or computer games.

In Sweden the development of modern, hightechnological society has meant mobility within the country as well as over the borders. People have to move where the jobs are. For the Swedes, the rural, kinship-based society, connected to specific localities, is gone and instead we experience the rise of an individual, more concerned with his or her "inner room" than the parental home of one's childhood or sacred places of traditional religion. For the new immigrants, mostly refugees but also labor immigrants, the relocation means a radical break from well-known places and ways of being in the world.

Technology has, of course, also created wellbeing for humanity. Formerly deadly diseases have been successfully combated. Although it is unequally used and it has negative consequences, technology has put humankind together, making us aware that we are many cultures but one humanity, and we have responsibilities for the practices we choose to put on earth. But it seems as if technology is too fragile to rely on when it comes to creating practices that can resist individual egoism, interests in profit and the destruction of places and meanings. Technical solutions are often negotiable, they are and they can be calculated in numbers. Behind the calculations there is an interest in making profit: society and business ask for solutions that are as cheap as possible.

It is precisely at this point Rappaport would advocate new approaches to science, technology, religion and ritual. He sees a dangerous evolution of humanity if science maintains its conviction that it is occupied only with theory construction, not realizing that "living systems under study have subjective as well as objective characteristics, [...] that opinion polls affect the opinions polled, and that studies of ecological systems are interventions into those systems" (Rappaport, 1999: 457). Referring to Heisenberg's recognition of indeterminacy, Rappaport distinguishes between the "Cartesian program," advocated by the scientists who look upon themselves as observers detached from the system they study, and the postmodern scientist, who is more reflexive in his role as scholar, aware of being both detached from the ecosystem and part of it. How to think of ecosystems implies a practice and furthermore it has consequences. If we conceptualize the ecosystem as an object, we will approach it as observers with gauges and chemical formulas, but if we see ecosystems as "umwelts" (a concept borrowed from Jacob von Uexküll, 1926), a web of meaningful relations, we are transformed from being observers into being subjects and part of this intricate web of relations.

The impossible distinction between being observer and participant is an insight for postmodern science to develop and thus the gap between philosophers and practicians is diminished: "Whereas a presumably detached modern science has attempted to confine itself to the construction of theory, leaving 'praxis' to 
engineers, plumbers, and electricians, recognition that participation in the world is unavoidable must lead postmodern science to incorporate considerations of practice into itself" (Rappaport, 1999: 457). Rappaport does not want to do away with science; his aim is to make a productive synthesis between science, religion, ritual and technology.

\section{TECHNOLOGY AND RITUAL IN TRADITIONAL SOCIETIES}

Rappaport's point is that indigenous peoples, like the Australian aborigines or the Maring people of New Guinea, have managed better than the Western world to build sustainable societies. They have worked as "scientists" by using observation and trial-and-error methods when it comes to relating to land, production and places, a kind of traditional ecological knowledge. But they have not separated this relation from meaning and tradition. The cultural ecologist Eugene Anderson echoes Rappaport when he says that over time traditional societies have managed much better than modern Western society to maintain a balance in their ecosystem. Anderson has analyzed the Mayan's ejido (a communally owned tract of usable land), the Chinese and their feng-shui notion and the Haidas' daily life on the northwest coast. In these societies praxis in the form of rituals has been a central means to keep that balance between the interest of the individual, the society and the environment. The inhabitants have all embedded rituals in their practical doings, and it seems that this "intermarriage" manages much better than have secular laws to prevent individuals from ruthless exploitation of the environment (Anderson, 1996: 15, 54, 73).

There is not only traditional ecological knowledge embedded in the rites, people invest emotions in their doings, and since rituals are social events, the entire society becomes involved. Individuals are not perfect calculators and they are prone to embrace positive illusions - if I just take a little bit of that, it won't destroy the ecosystem (see also Rappaport 1999: 130). Thus humans distort their constructions of reality, so these better fit with their hopes and dreams. According to Anderson, rituals regulate this egoistic and wasteful behavior and embed the message of responsibility in a more efficient way than do more secular ways. However, whereas traditional societies encode their resource systems in rituals, secular Westerners find it difficult to seriously consider these practices in environmental planning. But all traditional societies that have succeeded in resource management have done so partly by embedding their praxis in religion and rituals.

Whereas science only has technique to offer, it seems as if rituals add something of importance. It is in this context Rappaport presents rituals in a radically new way. During field studies on New Guinea he discovered how rituals among the Maring-speaking people worked to regulate the relationships not only between humans and society, but also between society and the environment, thus maintaining a balanced ecosystem. In his description of Maring life, he displayed ritual as a series of exchange that in the end affected the ecosystem. The slaughtering of pigs was conducted within a ritual framework and at a time where the animals had become more a burden than a resource for the community. Pig slaughtering was an ecological necessity but it was initiated religiously. In the Maring case, Rappaport said that ritual was of great help, since it "maintains an undegraded environment, limits fighting to frequencies which do not endanger the existence of the regional population, adjusts man-land ratios, facilitates trade, distributes local surpluses of pigs throughout the regional population in the form of pork, and assures people of high quality protein when they are most in need of it" (Rappaport, 1999: 41). Ritual becomes a key role in society, since its authority is based on both sustainable environmental traditions and religious claims. For the conservationist, environmental threats could be talked of as ecological components, but for the Maring it is not only the physical resources that are threatened, their whole life is at stake.

Religion and its practice, ritual, coexist today with science and its equivalence technology. It is noteworthy that when Rappaport formulates his general theory of ritual, his main interest is not worldviews; it is practice, and especially the ritual practice. There were special mechanisms in rituals that he saw had advantages compared to technology and language. Technological solutions are clearly intentional, practical acts, and as a scientific practice it follows the same rules wherever embedded in different societies. Hence, a sewage treatment plant reveals quite soon to the observer what is the practical 
intention of the machinery, even if some features, such as the staff's different clothes and doings, require cultural explanation referring to class, social stratification and education. But the purpose of the technological construction is clear: to purify water and make it drinkable. Technical solutions are, however, also negotiable: there are better or worse ways to do things and it is possible to count these ways in figures. That is why there is profit embedded in technology. Private companies or society want good solutions as cheap as possible.

\section{The Characteristics of Ritual}

It is the characteristics of ritual, according to Rappaport's theory, that I will primarily discuss, and the advantage he ascribed to rituals compared with other practices. Firstly, I give a brief presentation of Rappaport's theory and secondly, examples from the Mi'kmaq Indians of northeastern Canada and how they employed rituals in their efforts to protect a mountain from a super quarry on Cape Breton Island, Nova Scotia, a place they claimed was connected to their traditions and the culture hero Kluskap.

The basic function of ritual, according to Rappaport, is to be a specific kind of communication. He defines it (1999: 24) as "the performance of more or less invariant sequences of formal acts and utterance not entirely encoded by the performers". Unlike technology, the ritual act is not a direct expression of the performer's intention. Instead they communicate, according to Rappaport, important messages, founded in the moral and cultural code of society. This cultural code could melt down to some basic postulates, which he calls Ultimate Sacred Postulates. Although these postulates are culturally constructed, they are culturally viewed as inheriting unquestionable essence of values, and as such they cannot be either logically or empirically falsified within the system (Rappaport, 1999: 292). They are also of the utmost significance for how people conduct their lives, since they sanctify the ideology of the system which is the basis for the practices. And, unlike technology "and this is one of Rappaport's points " the message in the ritual communication is not negotiable for the participants. They are only the transmitters, not the encoders.

The central core in this definition is that the participants are not the original "author" of the rites they perform. Instead culture is the "author," and the task of the participant is to author a new rite that imitates the prescribed act. Hence the ritual admits a "double authorship," the prescribed act and the copied act by the performer. This double authorship is of the utmost significance for the intentionality of the rite. Since the prescribed act is already defined by culture, it is not dependent on the intention of the performer.

There are thus performative qualities in the prescribed acts, irrespective of the intention of the participant who performs the rite. If the performer follows the rules for the ritual, changes in one way or another occur, in spite of what he or she thinks of the rite. There are thus canonical messages built into the ritual, which the participants transmit, although these are not encoded by them, i.e. they are not the original authors of the rites. The participant must learn the meaning of the symbolic acts and how to perform them from culture. This makes rites basic, social acts, since they function at a higher level than other, more daily practices. This is why they can communicate reliable messages.

The most characteristic feature of humanity is the development of language and thus the ability to communicate. But, says Rappaport, language is not a reliable tool for transmitting messages, since it allows lies and alternatives. A rite diminishes these traps in communication, since the messages it transmits cannot be misinterpreted in its cultural context. Not can it offer alternatives. If you follow the cultural rules in performing the rite, it closes the door to these other alternatives. Hence, rites are more reliable for society than other practices, since they work independently of the intention of the individual, and thus they place obstacles to individuals' exploiting society or nature in an egoistic manner.

By transmitting unquestionable messages, rituals thus not only concern society and stabilize it. In the long run they also affect an even higher level, ecology. Rappaport put cybernetic thinking into ritual theory. Ritual runs like a thermostat: when you have fever, the body mechanisms try to regulate the temperature. When society and the environment were put under pressure in Maring society, because of too many pigs in the gardens, the traditional ritual of pig slaughtering and the distribution of meat put balance back again.

Since rituals both give models of and models for society they open up not only for explanations 
of the world but for a world full of meaning. The meaning for the participant in ritual activities is empowered in performing practices with other people and in specific places. Daily activities for many today often mean being a part of the market system and using technology as a helping hand. But, as mentioned above, technology and the market are two forces within modernity that have disembedded people from other people and places, including how to relate to places and humans. Transforming a place into an object in a Cartesian manner and talking about it as a physical object opens up for technology to do away with the parameter of meaning of how people relate to these places. What before was an emotional or religious defense of a place (it is beautiful or holy) is here put into figures. Places in this context have been transformed into objects ready to be used by technologists or to be defended by environmentalists, and it is easier for the market forces to negotiate with the opponents in figures than to discuss meaning and relations.

\section{The Negotiation of Place}

In 1989, when Grand Chief Donald Marshall initiated the investigation of rumors concerning the opening of a quarry at Kelly's Mountain on Cape Breton Island, it turned out that plans were already advanced. A local corporation (Kelly Rock) planned to open this quarry - one of the three largest in the world. Every week 150,000 tons of crushed gravel would be transported in ships carrying 60,000 tons to the eastern United States. The mining would last for 20-40 years, according to the calculations. By opening the mountain from the top, the so-called "glory hole method," the mining company guaranteed that the visibility of the operation would be minimized. However, new buildings and facilities were needed for the mining, i.e. a large shipping wharf, administrative buildings, crushers, stockpiles, conveyor belts, etc (Halifax Chronicle-Herald, March 27, 1993: B: 1, The Battle of Kelly's Mountain).

When the Mi'kmaq were informed of the plans, some Mi'kmaq traditionalists organized a peaceful chanting and drumming ceremony in Englishtown, a little village close to Kelly's Mountain (Cape Breton Post, September 26, 1989: $5)$. To establish a quarry on the mountain would be an insult to Mother Earth, said the Mi'kmaq, who also asserted that the mountain with its cave was the home of Kluskap and the place where he was expected to return to his people. Kluskap (or Glooscap, Gloscap, Gluskap, Gluscap) was a mighty culture hero, depicted in old myths among the Mi' kmaq and their neighboring tribes on the east coast of Canada. In the old stories he transformed the landscape by hunting a beaver, in deeds widely recounted and celebrated among the Mi'kmaq.

Many different groups of interests would formulate protests to protect the mountain. The green activists, including Greenpeace and people in the vicinity, were deeply concerned what would happen with the environment. Greenpeace had warned of coming demonstrations. Mi'kmaq cooperated with these groups and also gave environmental arguments for their engagement. In an article entitle Why we should preserve Kelly's Mountain, a number of rational reasons are given by the Mi'kmaq spokesman: "Here are some factors that will blow your mind: Up to 150,000 tons of rock per week will be washed and loaded on to 60,000 ton ships. The mountain would be one of the largest strip mines in the world. Plans are to blast half a million tons once a month" (MMNN, February 1992, vol. 3, no. 2: 26). The article shows that the Mi'kmaq spokesman was well prepared on the issue and that the Mi'kmaq also supported the environmental arguments from the Save Kelly's Mountain Society: the quarry would threaten local fishing and the tourist business (Halifax Chronicle-Herald, March 27, 1993: B: 1).

But it was only the Mi'kmaq who chose to protest by performing a rite on the mountain. Both the environmentalists and the Mi'kmaq would later on fight together to prevent the establishment of the quarry, but they employed partly different arguments. The environmentalists' arguments mostly concerned the environmental impact, which the authorities, helped by their employed expertise, could parry with other figures. Alf Hornborg writes (1994: 251) that the attempts in the Kelly's Mountain debate to break down the environmental problems into "valued ecosystems components" were an attempt to insert the problems into a rational, bureaucratic discourse which in the long run could cause the destruction of the mountain: "This approach immediately defines the proper relationship to the mountain as one of analysis, fragmentation and objectification, rather than holism and participation. Turning a mountain into gravel is 
facilitated by first breaking it down conceptually". Neil Evernden (1993: 9) has discussed the objectification of places and nature in a similar way: "Where once only an anguished cry could be expected in defense of a threatened mountain or an endangered species, now a detailed inventory and a benefit-cost analysis are sure to be forthcoming. The system will say all that needs to be said about the mountain - and say it with numbers".

The strategy for the technology " the ritual of science" was thus to change meaningful relations to a place into an object, surrounded by bureaucratic calculations, and its ritual regalia were not eagle feathers, honor songs and sweetgrass but negotiable figures and numbers. But precisely here lies the strength of a ritual: it displays indisputable values, non-negotiable. Maurice Bloch has written (1974: 71) how the ritual framing freezes the possibilities to protest during the performance: "You cannot argue with a song". The formalized language and the symbolic acts in rituals communicate in a way that make the message immune to protests. The message in this case was clear: do not desecrate sacred places. Hence, ritual on a societal level protected the sacred place, and on a higher ecological level it preserved it.

\section{Rituals as Protecting Places}

The Mi'kmaq thus added spiritual reasons to the more secular arguments that the environmental groups put forward. They stated that the mountain was sacred, an argument immune to bureaucratic calculations. They referred to tradition and ritual worship and asserted that the cave had always been the most sacred place in the world:

The site has been a place of worship and

it is believed the prophet will return to

the mountain to deliver believers. $\mathrm{Mr}$.

Herney compared it to the Second Coming

of Christ taught in the Catholic Faith

(MMNN, December 1992, vol.2, no. 12: 10).

Mr. Herney - Sulian Stone Eagle Herney was, at this time - one of the spokesmen for the Mi'kmaq. He claimed that the Mi'kmaq, just like Jews, Christians and Muslims, have their traditional holy places. As a spokesman for the SMS (Sacred Mountain Society, a Mi'kmaq organization formed during the fight with the authorities to preserve the mountain) Herney compared the status of Kluskap's Mountain with the Holy Sepulcher, the Wailing Wall and Mecca. In information which the Sacred Mountain Society spread and which they have written down from different meetings, papers and interviews on the radio, Herney says it would be unthinkable to build a superquarry at the Holy Sepulcher, and also to remove the Wailing Wall for a motel or to put a casino in Mecca. By this comparison he pointed out the impossibility of building profitable technological constructions at sacred sites. Technology concerns constructions of quarries and rituals concern sacred places, and since these practices are built on different premises - one for profit, one for worship - they belong to different spheres. It is one thing to question technology and technological solutions, another thing to violate undisputable values like holy places and rituals.

The references to a sacred mountain made it harder to meet the Mi'kmaq arguments, since the authorities were not used to discussing spiritual values side by side with plans for a secular, industrial project. The struggle would later on be a contest between the authorities' attempts to put the questions about sacredness into a language that was manageable for the bureaucrats, and the Mi'kmaq's resistance to this, which was to formulate a counter-language that would be immune to bureaucratic control. Ritual proved to be a good strategy. It displayed Mi'kmaq traditions, and made it clear that the mountain was one of these.

In the debate concerning the mountain, there were attempts to investigate its sanctity, how long rituals had been performed there, and if they still were. The Nova Scotia Museum thus examined the site in 1989 with the help of an archaeologist, a geologist and an ethnologist. They found (according to letters, sent to the Mi'kmaq Sulian Stone Eagle Herney from the Nova Scotia Department of Education, Nova Scotia Museum) evidence of recent activity (i.e. twentieth century) but it was harder to find evidence for a historical use, since organic material decay and the Mi'kmaq's oral tradition from historical times are gone. There are only few pieces of information left about how rituals in former times were conducted at Kluskap's Cave. Elsie Parsons (1925) refers to some of them: Gluskap's door is at St. Ann's. There you would throw in some dry punk and a 
little fish for his fire and food. You say, "I wish you give me good luck."...

"When you go to see Gluskap, at Smoket, Cape North," you say, "My dear Grandfather, I just come on your door. I want you to help me." You leave money inside the door, pieces of silver. You take two or three stones away with you, that's your luck.... At Cape Dolphin [Dauphin], Big Bras d'Or, there is a door through the cliff, Gluskap's door. Outside, there is a stone like a table. Indians going hunting will leave on it tobacco and eels, to give them good luck. They do this today (Parsons, 1925: 87).

Sulian Stone Eagle Herney confirms the place as a ritual site by referring to his talks with one of the Elders, the late deceased Annie Mae Bernard, also the daughter of the late Grand Chief. At a demonstration at Kluskap's Mountain in 1988 she told the participants that her father took his family and went to the cave twice a year. She confirms what Elsie Parsons wrote in 1925: at the mouth of the cave there are three flat rocks where they leave offerings (Network News, July/ August 1992, no. 2: 4). Herney also refers to his 82-year-old mother, who said it was sacred when she was a little girl.

But to discuss and argue about tradition, about what sacred status the mountain had in Mi'kmaq tradition and still has, was full of risks, since it meant playing on the premises of their counterparts, who had both defined the rules of this game and carried all weapons needed to play the game. The environmental activists experienced this and they had a hard time with small means finding the numbers that might convince the authorities, who had a battery of specialists matching the protests that came up. The Mi'kmaq thus chose another strategy and let their rituals play an important role in a praxis of protecting the place. The Mi'kmaq used varieties of them: the sweat lodge, drumming, powwows. It communicated to Canadian society a message about tradition and ultimate values, hard to attack for the authorities, since they could not argue with a ritual and a performance including drumming, dances and feathers.

The rituals also became important "fuel stations" for the participants in creating both individual and community meanings and a powerful counterbalance to the hard conditions on the reservations (Anne-Christine Hornborg
2005). A Mi'kmaq traditionalist confirmed some years later what an important learning process the fight was:

The mountain has to support the unity, of not only the Mi'kmaq population but also the world community, and that an awful lot of good has come out of the mountain. More human relations, healing, solidarity, union, unity has come out of that mountain than any of the gravel and granite that could been possibly shipped anywhere, more than any jobs that could have been created as a result of that superquarry. I think what the mountain has produced is something that can't be bought ... It produced a lot of pain, but it produced a lot of education, healing, tolerance, pride, spirituality and identity back to the people (Dalby, 1999: 12).

A ritual can be observed or practiced. When the scholar observes the ritual, an outsider perspective is created, in which symbols are interpreted, social structures revealed and traditions compared. But for the participant in the ritual, the most important part is not to reflect on how the ritual is constructed. The strength in ritual is in participating and the recurrent rites also played an important part for the Mi'kmaq, because the participants felt that they took part in a changing process that concerned their lifeworld on the reservations (see Rappaport 1999: 217). The mountain battle, with the above quotation in mind, could thus be likened to an immense, long-lasting ritual for the Mi'kmaq. It was from the place, the locality, that meaning was raised in order to save values larger than those which can be counted in money. And as for the Maring people on New Guinea, it was also for the Mi'kmaq not only physical resources that were threatened, their whole life on the reservations was affected and involved in the battle of the mountain.

\section{And the Quarry?}

The Mi'kmaq's and other activist groups' fear of environmental destruction could be countered by the authorities with promises of good technical solutions. But to question whether the mountain was a sacred place to the Mi'kmaq and argue against the rituals the Mi'kmaq set up was not that easy. Today it does not seem that the 
plans for a quarry will be realized. Many explain it in terms of the failure of the quarry company to fulfill all the commitments (Dalby, 1999: 10). This means that the environmental activists did a good job. Others say that the project proved not to be profitable. Moreover, the Mi'kmaq had managed successfully to broadcast their message and protests in society and in the media. A Mi'kmaq representative, appreciative of the attention that the issue had attracted, declared: "So I don't think any Dave McKenna [the man who hold a leading position in the quarry company] or any other company will ever be able to go to that mountain and attempt to make a superquarry out of it. I don't think the world community will allow it" (Dalby, 1999: 12).

\section{Rappaport Revisited}

The Mi'kmaq had communicated an important message in their rituals. It concerned the meaning of places, Mi'kmaq traditions and non-negotiable values. Turning the protest actions into ritual acts also implied the strategic use of a specific practice the authorities and the quarry company could not parry. It thus affected society and in the long run it also protected the environment. It was with eagle feathers, sweet grass, drums and the concept of Mother Earth that the mountain was protected from technological impact and thus saved for coming generations.

In Ritual and Religion in the Making of Humanity, one of the issues Rappaport discusses is the conceptions of the ecosystem. These conceptions are products of modern Western society, emanating from scientific epistemology rather than religious dogma. Rappaport also fidentifies "ecological thinking" in what he calls The Book. Although not expressed in terms of modern ecology, he suggests, such pre-modern thought is an adequate medium for protecting environmental values. His vision is to bring these two separate cosmologies closer, in order to emphasize the moral responsibility of humans everywhere on this planet. He advocates the Australian aborigines as a good example of this, and how their myths and concept of dreamtime tell us that taking moral responsibility for the world, and using it, is mutual work. Humanity has the power and the technology to destroy places and the ecosystem if we leave practice without moral consideration. It is even impossible, would
Rappaport say, to do something without simultaneously affecting social relations and the environment:

Ecosystemic conceptions which, in some non-Western societies, approach ultimate sacred status, are thus worthy of high sanctification by the religions of the West as well. High and explicit sanctification of such concepts and the actions they encourage not only might contribute to the preservation of the world's wholeness in the face of pervasive fragmenting and dissolving forces but could contribute to the revitalization of those religions in the age of increasing skepticism and cynicism toward them (Rappaport, 1999: 460).

The Mi'kmaq didn't dismiss the ecological arguments in their protest against the quarry, but they refused to treat their traditions and the sacred place by only referring to numbers and figures. The technological impact was in this case not separated from moral responsibility, and when practice implied a threat to non-negotiable values, in this case a sacred site, profit had to yield to nature.

The Mi'kmaq chose to employ rituals in saving their tradition and the environment. In her critical examination of modern science (1980), the environmental historian Carolyn Merchant puts her faith in the new scientific discipline of ecology, hoping that it will teach a new and better way of relating to the ecosystem. Another environmental historian, Donald Worster (1977), warns that ecology in itself is no guarantee, as it can be either used or abused in negotiating environmental issues. Rappaport's vision was to combine the moral efficacy of ritual with the analytical validity of ecological thinking. But how can modern, detraditionalized humans create such a synthesis, that recons with both practical effects and moral implications of human agency? Neither science nor its "ritual" technology has proven to be a good way.

Rappaport had the intention to construct a general theory of ritual for a global world, but, according to other ritual theorists, it is a mission impossible. Catherine Bell has firmly avoided such a theory. Instead she emphasizes that rituals are always bound to specific contexts, and thus impossible to disembed them from their context into one grand theory of ritual. Instead she sees how new ritualized practices have emerged in the Western world to fit modern man. Catherine 
Bell (1997: 241) even proclaims the birth of a new paradigm of ritual: "In this newer model, ritual is a medium of expression, a special language suited to what it is there to express, namely, internal spiritual-emotional resources tied to our true identities but frequently unknown and developed... The new paradigm is directed more inward than outward, apt to define community and society in terms of the self rather than the self in terms of the community".

The new rituals that Bell describes are individual-centered and thus not in tune with the more liturgical rites Rappaport used as the raw model in his theory, since these are embedded in tradition and Ultimate Sacred Postulates. According to Bell, the new paradigm of ritual cherishes the Self more than it concerns communities, traditions and ecology. The new, modern rites are more individual-centered than are the liturgical rituals which transmit the canonical messages encoded by tradition. This contemporary development of rites would thus be an obstacle to Rappaport's vision. They are designed for the needs of the individual and aimed to give good effects, preferably as quick as possible, for the performer. The individualcentered rites cannot transmit social messages because their major concern is the effects on the individual. Neither could they be basic acts for society. Instead they benefit the market system, since the occupation with the Self gives less attention to social structure and environmental issues. For people making a profit on the market system, it is thus a useful strategy to promote the self-made rites, since they transform structural problems into individual problems.

Rappaport's visions, however, included the importance of practice, an awareness of the qualities in the different kinds of acts humans perform and how they affect society, humankind and, in the long run, the environment. He saw very clearly what the consequences of the market system were. In his ambition to advocate tradition and the "The Ultimate Sacred Postulates," Rappaport was worried (1999: 442) that these would be replaced by the ideology of the market and thus warns of the consequences: "Indeed, if the business of America is business, business, profit, private enterprise and consumption are tacitly declared basic, or ultimate values and as such enjoy a degree of sanctity equal to that of life, liberty and the pursuit of happiness, with which they may well be conflated."

\section{REFERENCES}

Bauman, Z.: Modernity and the Holocaust. Cornell University Press, Ithaca, New York (1989).

Bell, C.: Ritual: Perspectives and Dimensions. Oxford University Press, New York, Oxford (1997).

Bloch, M.: Symbols, Song, Dance and Features of Articulation. Archives européennes de sociologie, 15: 55-81 (1974).

Cape Breton Post: Micmac protest proposed quarry project. September 26, 1989, p. 5 (1989).

Halifax Chronicle-Herald: Thunder over the Mountain: Micmacs developer square off over Kelly's. March 27, 1993, p. B: 1 (1993).

Dalby, S.: Globalization and the Natural Environment: Geopolitics, Culture and Resistance. Paper presented to the International Roundtable on the Challenges of Globalization in University of Munich, March 1999 (1999).

Evernden, N.: A Natural Alien. University of Toronto Press, Toronto [(1985) 1993].

Hart, K.: Forword, pp xiv-xxi. In: Ritual and Religion in the Making of Humanity. R. Rappaport. Cambridge University Press, Cambridge (1999).

Heelas, P.: The Spiritual Revolution: From 'Religion' to 'Spirituality', pp. 357-379. In: Religions in the Modern World. L. Woodhead, P. Fletcher, H. Kawanami and D. Smith (Eds.). Routledge, London and New York (2002).

Hornborg, Alf: The Power of the Machine: Global Inequalities of Economy, Technology, and Environment. Alta Mira Press, New York (2001).

Hornborg, Alf: Environmentalism, Ethnicity and Sacred Places: Reflections on Modernity, Discourse and Power. Canadian Review of Sociology and Anthropology, 31(3): 245-267 (1994).

Hornborg, Anne-Christine: A Landscape of Left-Overs. Lund Studies in History of Religions, vol. 14. Lund, Almqvist \& Wiksell International (2001).

Hornborg, Anne-Christine: Eloquent Bodies: Rituals in the Context of Alleviating Suffering. Numen, 52(3): 356-394 (2005).

Merchant, C.: The Death of Nature: Women, Ecology and the Scientific Revolution. 1980, Reprint edition, Harper, San Francisco (1990).

Micmac Maliseet Nations News (MMMN): Why we should preserve Kelly's Mountains'. February 1992, 3(2): 26 (1992).

Micmac Maliseet Nations News (MMNN): Crushed stone for fixed link could ruin sacred mountain: N.S. Micmacs angry at quarry idea to help build link. December vol. 2 1992, 12:10 (1992).

Network News: Nova Scotia Environmental Network: July/August 1992, 2: 4 (1992).

Rappaport, R.: Pigs for the Ancestors: Ritual in the Ecology of a New Guinea People. 1968, Second ed., Yale University Press, New Haven (1984).

Rappaport, R.: 1999. Ritual and Religion in the Making of Humanity. Cambridge University Press, Cambridge (1999).

Save Kelly's Mountain: The Battle of Kelly's Mountain. Information paper handed out by the Save Kelly's Mountain Society.

Uexküll, J. von.: Theoretical Biology. Transl. by D. L. MacKinnon. International Library of Psychology, Philosophy and Scientific Method. Kegan Paul, Trench, Trubner and Co, London (1926).

Worster, D.: Nature's Economy: A History of Ecological Ideas. 1977, $2^{\text {nd }} \mathrm{Fd} .$, Cambridge University Press, Cambridge (1994). 